DOI: $10.52950 / T E .2021 .9 .2 .003$

\title{
A STUDY OF PARENTS READING ALOUD HABITS WITH RESEARCH ON READING ALOUD APPLIED TO RESEARCH-BASED PRACTICES FOR PROMOTING STUDENTS' INTRINSIC MOTIVATION TO READ
}

\section{LINDA FÄLTH}

\begin{abstract}
:
Read-alouds play an important role in young children's literacy development. This study investigates how, and to what extent, Swedish parents of children aged 1-16 engage in reading aloud. Previous research on reading aloud is also applied to research-based practices for promoting students' intrinsic motivation to read and discussed in the present study. The results show that 9 out of 10 parents read aloud to children aged 0-4 years while only 4 of 10 read aloud to children aged 10-12 years. Several content areas that overlap were found where research on children's own reading can be easily transferred to the area of reading aloud.
\end{abstract}

\section{Keywords:}

children; motivation; pupils; reading aloud; reading

JEL Classification: 129

\section{Authors:}

LINDA FÄLTH, Linnaeus University, Sweden, Email: linda.falth@Inu.se

\section{Citation:}

LINDA FÄLTH (2021). A study of parents reading aloud habits with research on reading aloud applied to research-based practices for promoting students' intrinsic motivation to read. International Journal of Teaching and Education, Vol. IX(2), pp. 30-41., 10.52950/TE.2021.9.2.003 


\section{Introduction}

One of the most recommended practices to help children learn languages is through parents and teachers reading books aloud (Neuman et al., 2000). Research has shown that readalouds can help increase children's vocabulary (Beck et al., 2002; Pollard-Durodola et al., 2011) and oral comprehension skills (Cunningham \& Stanovich, 1997). A connection between reading aloud and children's phonological awareness, understanding of the connection between letter and sound, ability to know and use situation-independent language and positive attitudes towards reading has been found (Leseman \& Jong, 1998). The National Early Literacy Panel (2009) reported in a meta-analysis that teachers or parents reading aloud to children can raise their verbal language abilities and knowledge acquired from printed materials. During read-alouds, the child gets to know the peculiarity of the written language which benefits their future learning to read. Also, children who have been read aloud to have gained an understanding of the different functions of written language, which gives them good prerequisites to learn and to crack the reading code (Wolff, 2009). Reading aloud not only teaches children new words and provides syntactic knowledge, but it also hopefully arouses interest in reading (Wolff, 2009). Through reading aloud, pupils' familiarity with different genres can be expanded and children are allowed to encounter a more advanced vocabulary and complex sentence structure. Pupils who cannot read on their own also have the opportunity to develop their conceptual perception, imagination, and creativity through reading aloud (DeBruin-Parecki \& Squibb, 2011).

Reading aloud is often associated with reading for young children or younger students. The present study was conducted to examine the extent to which Swedish parents of children aged 1-16 engage in reading aloud at home. While many children continue to enjoy being read to well beyond the early years of schooling (Merga, 2018), reading aloud at home may end while children are still young and enjoy being read to (Scholastic, 2015, 2016a, 2016b). Over a third of Australian children between six and eleven, whose parents no longer read to them, wished they had continued (Scholastic, 2016a). In the States, surveys on reading aloud are conducted every two years. The latest survey in 2019 , showed that reading aloud often takes place for children up to the age of five, then as the children start reading themselves, many parents stop reading aloud. In Sweden, between 1984 and 2003, measurements were carried out every two years on children's use of media, how often they take part in cultural eventsand their reading habits. (Filipson, 1999; Filipson \& Abrahamsson, 2001; Lund, 2003). The last survey found that the proportion of children who had books read to them daily decreased from $80 \%$ in 1984 to $74 \%$ in 2003 . The time spent on reading aloud had been halved, from half an hour to a quarter of an hour. In 2012, a similar study to find out in which direction the development had gone since 2003, was conducted among 1000 Swedish parents with children aged 0-9. The study concluded that only $35 \%$ of parents read daily to their children and $30 \%$ read several times a week, but not every day. The proportion of children being read aloud to this tend to have continued to decrease since 2003 (Filipson \& Abrahamsson, 2001; Lund, 2003). One purpose of the present study is to investigate how, and to what extent, Swedish parents of children aged 1-16 engage in reading aloud today, almost 20 years after the last major survey.

The environment where the children are brought up as well as their ability to cope with school plays a major role in language development. Books and reading do not belong to everyday life for all pupils, which means that preschool teachers need to become role models and make 
reading aloud part of the school day (Damber, 2015). Pupils who have difficulty sitting still and listen to read-alouds require a reading situation that is prepared and structured to capture their interest and create commitment. Reading aloud is much more than a quiet intricate moment. It develops vocabulary, a sense of sound, and reading comprehension as well as social development, and metacognitive abilities. Parents' knowledge of the importance of reading aloud for children's development is necessary to perform qualitative read-alouds. Reading promotion initiatives achieve the best results as the initiatives meet the parents' own needs. The effects of reading promotion efforts on parents' reading aloud could be improved if the efforts contained instructions on how to develop, rather than merely inform about the importance of reading aloud (Kouri, 2018).

Reading aloud has traditionally been used in preschools and schools as a transitional activity, often as a soothing element during a long day. But researchers agree that reading aloud should be given more space than that. Educators need to be aware that reading aloud is an activity that requires careful preparation and goals. Reading aloud invites children to fantasy worlds, expands their imagination, and teaches them to understand what stories are about. They are also language-developing moments (Damber, 2015; Klein \& Kogan, 2013; Thomas et al., 2011). Internationally, reading aloud seems to be mostly used for entertainment and/or disciplinary purposes in the preschool classroom rather than having a didactic function. The positive short-term effects of reading aloud to children are validated based on the language abilities of young children throughout the primary grades (Klein \& Kogan, 2013). Positive longterm effects are validated based on the language abilities of older children (Kloosterman et al., 2011). Factors that appear to positively influence children's language are frequency of reading aloud, the dialogue that occurs throughout the reading, and the level of the children's engagement that occurs during the reading experience (Fisher et al., 2004; Keller, 2012; Klein \& Kogan, 2013; Kloosterman et al., 2011; Lane \& Wright, 2007; Worthy et al., 2012). In a Swedish study, Alatalo and Westlund (2019) investigated how preschool teachers reason about reading aloud. Teachers were found to be aware of the importance of reading aloud but that it was not practiced consciously to develop children's language or to challenge their cognitive thinking ability. The results also show that the teachers prefer fairytales to non-fiction texts, as they feel more comfortable with that genre. Although the teachers were aware of the importance of developing children's vocabulary, they only used terms and concepts (i.e., phonemic awareness, making inferences) that indicated knowledge about language learning and language development to a small extent. In another study, Damber (2015) described and analyzed how read-alouds, using children's literature, were carried out in 39 preschools. The results show that read-alouds mostly occurred once per day, often in the afternoon while the teachers were waiting for the parents to collect their children. The read-aloud moments were seldom planned or embedded in a context.

Elbro's (2004) review of 21 studies on how reading aloud at home affects pupils' reading development in school shows that pupils' vocabulary is expanding and that children who are read to at home develop a greater desire to read. However, he found that the overall reading development was not affected to any great extent as well as without the child actively participating in the read-aloud it will only have a small language developing effect. In line with this, Alatalo and Westlund (2019) argue for the need for greater awareness of dialogic reading. This means that such a dialogue is conducted with the children that they become active and engaged. Signs of such a commitment can be that the children are curious and ask questions and/or make different connections to the text. As one child engages in a dialogue by asking 
questions or reflects over the text, the other children can be let into the dialogue when the adult follows up the questions. To ensure that reading aloud facilitates the children's language learning, preschool teachers need time to plan their activities as reading aloud must be structured to have the desired effects (Alatalo \& Westlund, 2019; Elbro, 2004; Klein \& Kogan, 2013).

In a study by Gambrell (2011), a set of key research-based practices for promoting students' intrinsic motivation to read (Seven Rules of Engagement), is provided. By starting from the Seven Rules of Engagement, teachers can create increased reading engagement in children and young people. Motivation to read can be defined as the likelihood of engaging in reading or choosing to read (Gambrell, 2009, 2011). The engagement perspective is linked to motivation and has strong implications for practice (Tracey \& Morrow, 2006). In the result section, these seven rules will be explained in more detail and linked to research on reading aloud. Reading aloud has long been an important method for many teachers, both in preschool and school (Hindman et al., 2008; Marchessault \& Larwin, 2013). Several empirical studies indicate that teachers reading aloud in a variety of ways functions as an effective support in the first stages of learning to read (DeBruin-Parecki \& Squibb, 2011). A study by Aram and Biron (2004) shows that talking to children about book content in connection with reading aloud can have effects on children's phonological awareness and letter knowledge. Reading aloud to older students can contribute to increased student engagement, understanding, and motivation (Marchessault \& Larwin, 2013). A study by Foy and Mann (2003) showed that children who had many reading experiences through different media, as well as parents actively involving them in reading activities, had greater phonological awareness, letter knowledge, and vocabulary than children who did not receive this form of stimulus. Karweit (1989) compared the effects of reading aloud at home to preschool and school. Reading aloud in school affects the dialogue about the text content as not everyone has room to speak due to a large number of pupils. The pupils can then become passive, and it can result in one-way communication from teacher to pupils. Reading aloud often becomes more interactive at home as it is usually done for one to two children. According to Karweit, a language-developing readaloud contains questions before, during, and after the reading. For larger groups, the dialogues about the book should not be long discussions. Hindman et al. (2008) observed 130 children in their homes and preschools as well as interviewing children, parents, and teachers. They concluded that children's vocabulary was affected by how, and how much, the adults talked to the children when reading.

\section{Method}

\subsection{Participants}

Informants have been recruited on behalf of the LegiLexi foundation (www.LegiLexi.org) via the Norstat internet panel, which consists of approximately 70.000 members. Invitations to the survey have been sent to men and women aged 25-65. The composition of the sample population is representative of the population with regard to gender, age, and region (Legilexi). A total of 1005 individuals with children aged 0-18 participated in the study, $65 \%$ had children aged $0-9$ and $35 \%$ had children aged $10-18$.

Characteristics of the participants:

Parents with children aged 0-4 $(n=365)$ 
Parents with children aged 5-6 $(n=171)$

Parents with children aged 7-9 $(n=256)$

Parents with children aged 10-12 $(\mathrm{n}=296)$

Parents with children aged 13-18 $(n=433)$

The overlap is due to some parents having children of different ages.

\subsection{Procedure}

The first section in the results: The survey was conducted using web interviews where the interviewees were contacted in advance to book an appointment. The interviews were conducted individually and took about 30 minutes. The second section in the results: Gambrell's (2011) Seven Rules of Engagement for promoting students' intrinsic motivation to read is applied to the research on reading aloud for children. Each of the seven rules is reviewed separately and linked to research on children's reading development (Gambrell, 2011). They are then connected to the present research on reading aloud.

\section{Result}

This section consists of data a) about the frequency of parents reading aloud to their children, b) about how parents read aloud to their children and c) on research on reading aloud applied to the Seven Rules of Engagement for promoting student's intrinsic motivation.

\subsection{Survey results}

The average reading time per occasion is unchanged since 2012 (YouGov). Parents who read aloud to their children at least once a week, read an average of 20 minutes per occasion. Of 545 respondents, $25 \%$ state that they read $1-10$ minutes/occasion, $27 \%$ read $11-15$ minutes/occasion, $27 \%$ read $16-25$ min/occasion, and $21 \%$ of the respondents state that they read more than 26 minutes/occasion. The average reading time per occasion does not change with the children's age, but as the frequency of reading aloud decreases as the children get older, the average reading time per week also decreases.

Table 1. The frequency, stated by the parents, of reading aloud to the child in $\%$.

$\begin{array}{lllll}\begin{array}{l}\text { Every } \\ \text { day }\end{array} & \begin{array}{l}\text { Several } \\ \text { times a } \\ \text { week }\end{array} & \begin{array}{l}\text { Once a } \\ \text { week }\end{array} & \begin{array}{l}\text { Once a } \\ \text { month }\end{array} & \begin{array}{l}\text { Rarely } \\ \text { or never }\end{array} \\ & & & & \end{array}$

Children aged $0-4$

$(n=365)$

57

23

8

6

4

Children aged 5-6

$(n=171)$

52

23

9

12

4

Children aged 7-9

$(n=256)$ 
Children aged 10-12

$(\mathrm{n}=296)$

19

29

17

15

20

Children aged 13-16

$(n=433)$

10

11

12

16

52

The type of books that parents read to their children is strongly linked to the age of the children. Those who have younger children mainly read fairy tales and parents who have older children mainly read chapter books or fiction. An overlap due to some parents having children of different ages is found in the results. Parents express that it is important to read aloud to their children. Both children and parents enjoy read-alouds. Parents also express that they hope that it will lead to an increased interest in reading and books. Despite this, just over $50 \%$ of the parents participating in this study wish they would read more to their children.

Table 2. How parents read with their child/children

\begin{tabular}{|c|c|c|c|c|c|}
\hline & $\begin{array}{l}\text { Parent } \\
\text { read } \\
\text { aloud }\end{array}$ & $\begin{array}{l}\text { We read } \\
\text { at the same } \\
\text { time, but in } \\
\text { different } \\
\text { books }\end{array}$ & $\begin{array}{l}\text { We listen } \\
\text { together to } \\
\text { an audio- } \\
\text { book }\end{array}$ & $\begin{array}{l}\text { We read } \\
\text { at the } \\
\text { same time } \\
\text { in the same } \\
\text { book }\end{array}$ & $\begin{array}{l}\text { I don't } \\
\text { read with } \\
\text { my child/ } \\
\text { children }\end{array}$ \\
\hline $\begin{array}{l}\text { Children aged } 0-4 \\
(n=365)\end{array}$ & 92 & 11 & 9 & - & 3 \\
\hline $\begin{array}{l}\text { Children aged 5-6 } \\
(n=171)\end{array}$ & 93 & 12 & 16 & 1 & - \\
\hline $\begin{array}{l}\text { Children aged } 7-9 \\
(\mathrm{n}=256)\end{array}$ & 89 & 23 & 14 & 6 & 2 \\
\hline $\begin{array}{l}\text { Children aged } 10-12 \\
(n=296)\end{array}$ & 71 & 37 & 12 & 4 & 7 \\
\hline $\begin{array}{l}\text { Children aged } 13-16 \\
(n=433)\end{array}$ & 36 & 33 & 8 & 7 & 30 \\
\hline
\end{tabular}

When asking the parents about their reading habits, $67 \%$ answered that they read aloud to their children, $23 \%$ answered that they read together with their children but in separate books, $10 \%$ answered that they listen to an audiobook together with their children, $5 \%$ answered that they read in the same book as the child but each one quietly for themselves, $14 \%$ answered that they do not read at all with their children. 
The most common reason for parents not reading aloud to their children is time. Many also express that the children have grown up, lack energy, and prioritize other activities. As in 2012, reading aloud is in third place, after screen time and play, when measuring activities parents and children do together. While lack of time is the most common reason for not reading more to their children, we see that reading takes place mainly on weekdays, that it drops on weekends, and that it is lowest during holidays. This tendency intensifies as the children get older. Parents read aloud to their children for many reasons. The most important reason is the different aspects of the children's development, such as language development, vocabulary, reading comprehension, and it being educational. The quiet intricate moment together and that it is fun and something you like to do, is also appreciated by many.

\subsection{Reading engagement and reading motivation - Seven Rules of Engagement}

A study by Gambrell (2011) shows, based on previous research, how teachers can create increased reading engagement in children and young people by applying the Seven Rules of Engagement. These rules provide key research-based practices for promoting students' intrinsic motivation to read. Below, attention is drawn to how these rules/statements (Gambrell, 2011) can be understood and useful in the context of research conducted in the field of reading aloud to children. The first rule: Students are more motivated to read when the reading tasks and activities are relevant to their lives emphasizes the importance of working with tasks that are relevant to the students. Students need to feel that the content touches and interests them as they need to be able to make connections to their own lives and the society they live in (Hulleman et al., 2010). When applying this to reading aloud, by using texts that concern and interest the students, leads to greater commitment and involvement. A variety of text types and genres are important to engage the listeners (c.f. Hindman et al., 2008; Marchessault \& Larwin, 2013). This also applies to what Gambrell (2011) addresses in the second rule: Students are more motivated to read when they have access to a wide range of reading materials which concerns offering students different genres as well as alternating types of media and modalities. It is important to give students the opportunity to read texts both online and in printed format as well as alternating factual texts with fictional texts. Students should also be encouraged to read newspapers and magazines (McGill-Franzen \& Allington, 1993; Neuman \& Celano, 2001). Reading aloud is not only reserved for books. It is possible to read aloud from other media, for example, from newspapers or magazines.

The third rule: Students are more motivated to read when they have ample opportunities to engage in sustained reading. This emphasizes the importance of continuity and that time must be set aside for reading in school. If students are allowed to read often and for longer periods at a time, they will be more motivated to read (Brenner et al., 2009). The same principle applies to read-alouds. There must be continuity and time set aside for listening as both contribute to an increased motivation among students (Alatalo \& Westlund, 2019; Elbro, 2004; Klein \& Kogan, 2013). However, reading aloud to children without processing the textual content does not have any major effects on children's vocabulary, literacy development, and awareness of narrative structures or acquisition of the more complex grammatical structures of the written language (Klein \& Kogan, 2013). Rule number four: Students are more motivated to read when they have opportunities to make choices about what they read and how they engage in and complete literacy tasks. This emphasizes that students become more involved if they are allowed to participate and influence what they read. Feeling that you can influence the choice 
of literature can contribute to an increased reading engagement and thus take on subsequent tasks with a greater interest. As not all students are readers, it is important that you as a teacher have made the first selection of titles for the students to choose from. How students are allowed to participate is an important issue when choosing books for both reading aloud and reading on their own (Patall et al., 2010). Through reading aloud, the student can meet more advanced texts that open up for different reading comprehension.

The Fifth rule: Students are more motivated to read when they have opportunities to socially interact with others about the text they are reading. Allowing students to interact with others during and after the reading has been shown to create increased reading engagement. Being able to share your reading experience and put what you have read into words, at the same time as you hear other people's interpretations, means that both your own reading (Applebee et al., 2003) and the effect of reading aloud deepen (Aram \& Biron, 2004; Hultgren, 2015). Social interactions and shared experiences are acknowledged as an important impetus to the enjoyment of books, thus both reading individually and reading aloud has a valuable social purpose (Baker \& Wigfield, 1999). Reading aloud enables the teacher to create challenging teaching. By choosing texts that go beyond the students' previous reading experiences, it gives the students an opportunity to socially interact with others as they share the same reading experience. This can also contribute to increased reading engagement (Aram \& Biron, 2004).

The last two rules: Students are more motivated to read when a) they have opportunities to be successful with challenging texts and, b) classroom incentives reflect the value and importance of reading. There is empirical evidence that indicates that teachers reading aloud in a variety of ways functions as effective support when learning to read (DeBruin-Parecki \& Squibb, 2011). Giving students texts that are challenging is important for creating reading engagement. Being seen and receiving positive feedback from your teacher are also factors contributing. It is important to support students reading development in different ways. Reading aloud and book talks are some good examples (Schunk \& Zimmerman, 1997) of shared reading experiences that can contribute to students' reading development. Wang and Holcombe (2010) argue that it is important that the teacher puts the reading in focus by letting it take time and space in everyday teaching. In that way, the teacher becomes a role model for the students. Reading aloud gives the students a deeper understanding of the language as well as contributing to the student's personal development (Cothern \& Collins, 1991).

\section{Discussion}

The results from this study show that $50 \%$ of all parents with children aged $0-9$ read aloud to their children every day. At the same time, the survey shows that the number decreases as the children get older. This can be compared with the survey from 2012, which showed that only $35 \%$ of parents with children of the same age read aloud to them daily (Reading Movement, 2012). There has thus been a 15\% increase in reading aloud for children aged 0 9 between 2012 and 2019. Research shows that read-alouds are important for children of all ages, not only the youngest (Chambers, 2014). Despite this, only $19 \%$ of parents read aloud to children aged 10-12, according to the results of the present study. Furthermore, the results show that several different points have common grounds in the research on reading aloud and the students' own reading. For example, the motivation linked to one's own reading also applies to reading aloud. According to Fisher et al. (2004), Hickman et al. (2004), and Merga (2018), reading aloud has a number of advantages and positive effects on children's language 
development, regardless of their age. Reading aloud gives opportunities for the listeners to create mutual experiences that they can process together. It allows the content of the text to be in focus as the listener does not have to spend energy on the reading itself. Read-alouds also give the children access to texts they otherwise would not have come in contact with. For many pupils who struggle with decoding or who are learning to read fluently, comprehension strategies can be taught through these oral language opportunities (e.g., reading aloud). The children who have been read to frequently have better language skills than the children who have not been read to, to the same extent (Hickman et al., 2004; Merga, 2016). Both this study and several others show that there are large variations in frequency, and how the children are read to in different families.

Several researchers emphasize the impact that reading aloud can have on students' interest in, and curiosity about, reading and books. They also suggest that reading aloud is not important in itself (e.g., Mol et al., 2008), it is the quality of the discussions about what is read that is crucial. Reading promotion initiatives that strive to increase the amount of reading aloud in the home will conflict with the quality aspect if the only goal is to read more. It is possible that reading promotion initiatives that emphasize the amount of reading take for granted that discussions and interaction around what is read are a natural part of reading aloud. However, according to Huebner and Meltzoff (2005), the quality of reading aloud does not increase at the same rate as the quantity of reading aloud as parents, even though they read more, do not have a dialogue with the child about what has been read. In the same way as reading on your own (Gambrell, 2011), reading aloud can also lead to students being inspired to develop their vocabulary when they hear new words, they find interesting. In addition, the pupils should throughout the reading, have the opportunity to make discoveries as well as through associating events in the story remember things about themselves. Reading can in this way make it possible for students to gain a deeper understanding of themselves and as they use it in different textual contexts it also develops their language (Cothern \& Collins, 1991). One important difference between pupils reading quietly on their own and pupils listening to a parent or teacher reading aloud is that when being read aloud to, the child gets the opportunity to listen to texts they might otherwise never have come in contact with. This enables a wider insight into, and knowledge of, different genres and text types. Research shows that it is important to let pupils engage in discussions after reading aloud to have a positive effect on language development. Through reading aloud, the reader can be a good role model for the students by, for example, reflecting on the content of the text to locate events that the students need to discuss. Reading aloud is therefore about creating motivation for reading on your own. As experiencing the value of reading can help students to identify themselves as readers, it encourages them to participate in the classroom reading community.

In line with the results of this study, several researchers emphasize the positive effects of reading aloud on children's own reading. Hultgren (2015) also suggests that it is important for adults themselves to have an interest in reading as well as being a good role model for the children and convey a positive image of reading aloud. Fox (2013) describes the importance of starting reading aloud early for children to make reading a habit as it can help children become good listeners at an early age and also make reading fun. As there is a significant difference in the degree of difficulty of a text a student can read and understand depending on whether they are being read to, or read for themselves, reading aloud benefits all ages. Through read-alouds the students can therefore benefit from more complex texts which will give them greater reading experiences. Taking part in read-alouds will therefore increase 
children's opportunity to be equally included in conversations to deepen and expand their understanding.

\section{Conclusions}

The results from the web interviews showed that the frequency of reading aloud decreases as the children get older but the average reading time per occasion does not change. The main reason for reading aloud found was the child's language development, however, other reasons such as creating a quiet intricate moment together and being enjoyable were also contributing factors. The effectiveness of reading aloud can be increased if situations are created in which children are engaged during their participation in read-alouds. The parent or teacher can also engage pupils before beginning the reading by creating anticipation about the book. They can, for example, use the book cover to ask questions and commenting on characters and scenarios depicted in the picture. Reading aloud has many advantages, it gets children interested in literature, facilitates discussions or book discussions, and can create a different, more equal relationship between teachers and students than the one that usually dominates in school contexts. This study shows many advantages of reading aloud as well as connects the findings to research on factors contributing to children's motivation to read. This can be used as a foundation for further research within the field of reading development.

\section{References}

Alatalo, Tarja \& Westlund, Barbro, (2019) Preschool teachers' perceptions about read-alouds as a means to support children's early literacy and language development. Journal of Early Childhood Literacy, p.146879841985213.

Applebee, Arthur N, Langer, Judith A, Nystrand, Martin, \& Gamoran, Adam (2016) Discussion-Based Approaches to Developing Understanding: Classroom Instruction and Student Performance in Middle and High School English. American Educational Research Journal 40, no. 3, 685-730.

Aram, Dorit \& Biron, Shira, (2004) Joint storybook reading and joint writing interventions among low SES preschoolers: differential contributions to early literacy. Early childhood research quarterly, 19(4), pp.588-610.

Beck, Isabelle, McKeown, Margeret, Kucan Linda (2002) Bringing Words to Life: Robust Vocabulary Instruction. New York: Guilford.

Brenner, Devon, Hiebert, Elfrieda \& Tompkins, Renarta (2009) How much and what are third graders reading. Reading more, reading better 118-140.

Cothern, Nancy \& Collins, Maritha (1991) An exploration: Attitude acquisition and reading instruction. Literacy Research and Instruction, 31(2), 84-97.

Cunningham, Anne \& Stanovich, Keith (1997) Early reading acquisition and its relation to reading experience and ability 10 years later. Dev. Psychol. 33 934-945.

Damber, Ulla (2015) Read-alouds in preschool-A matter of discipline?. Journal of Early Childhood Literacy, 15(2), 256-280.

DeBruin-Parecki, Andera \& Squibb, Kathryn (2011) Promoting at-risk preschool children's comprehension through research-based strategy instruction. Reading Horizons: A Journal of Literacy and Language Arts, 51(1), 5.

Filipson, Leni (1999) Barnbarometern 98/99: 3-8 åringars kultur-och medievanor. Mediamätning i Skandinavien.

Filipson, Leni \& Abrahamsson, Anna (2001) Barnbarometern 2000/2001: 3-8 åringars kultur-och medievanor. Mediamätning i Skandinavien. 
Foy, Judith G. \& Mann, Virginia (2003) Home literacy environment and phonological awareness in preschool children: Differential effects for rhyme and phoneme awareness. Applied Psycholinguistics, 24, 1, p 59-88

Fox, Mem (2013) What next in the read-aloud battle? The reading teacher 67 (1): 4-8.

Gambrell, Linda (2009) Creating opportunities to read more so that students read better. Reading more, reading better, 257-258.

Gambrell, Linda (2011) Seven rules of engagement: What's most important to know about motivation to read. The reading teacher, 65(3), 172-178.

Hindman, Annemarie, Connor, Carol, Jewkes, Abigail \& Morrison, Frederick (2008) Untangling the effects of shared book reading: Multiple factors and their associations with preschool literacy outcomes. Early Childhood Research Quarterly, 23(3), 330-350.

Huebner, Colleen \& Meltzoff, Andrew (2005) Intervention to change parent-child reading style: A comparison of instructional methods. Journal of Applied Developmental Psychology, 26(3), 296313.

Hulleman, Chris, Godes, Olga, Hendricks, Bryan \& Harackiewicz, Judith (2010) Enhancing interest and performance with a utility value intervention. Journal of educational psychology, 102(4), 880.

Karweit, Nancy (1989) The effects of a story-reading program on the vocabulary and story comprehension skills of disadvantaged prekindergarten and kindergarten students. Early Education and Development, 1(2), 105-114.

Klein, Oliver \& Kogan, Irena (2013) Does reading to children enhance their educational success?. Child Indicators Research, 6(2), 321-344.

Kloosterman, Rianne, Notten, Natascha, Tolsma, Jochem \& Kraaykamp, Gerbert (2011) The effects of parental reading socialization and early school involvement on children's academic performance: A panel study of primary school pupils in the Netherlands. European' Sociological Review, 27(3), 291-306.

Kouri, Elisa (2018) Högläsning i hemmet: En kvantitativ studie om hur läsfrämjande insatser inverkar på högläsningen i hemmet.

LegiLexi. www.legilexi.org

Lund, Anna (2003) Barnbarometern 2002/2003: 3-8 åringars kultur-och medievanor. Mediamätning i Skandinavien.

Marchessault, Jennifer Larwin, Karen (2013) Structured Read-Aloud In Middle School: The Potential Impact On Reading Achievement. Contemporary Issues in Education Research (CIER), 6(2), 241-246.

McGill-Franzen, Anne \& Allington, Richard (1993) Flunk'em or get them classified: The contamination of primary grade accountability data. Educational Researcher, 22(1), 19-22.

Merga, Margeret \& Ledger, Susan (2018) Parents' views on reading aloud to their children: Beyond the early years. Australian Journal of Language and Literacy, The, 41(3), 177.

National Early Literacy Panel, (2009) Developing Early Literacy: Report of the National Early Literacy Panel. Jessup, MD: National Institute for Literacy.

Neuman, Susan \& Celano, Donna (2001) Books Aloud: A campaign to" put books in children's hands". The reading teacher, 54(6), 550-557.

Neuman Susan, Copple Carol \& Bredekamp Sue (2000) Learning to Read and Write: Developmentally Appropriate Practices for Young Children. Washington, DC: National Association for the Education of Young Children New York.

Patall, Erika, Cooper, Harris \& Wynn, Susan (2010) The effectiveness and relative importance of choice in the classroom. Journal of Educational Psychology, 102(4), 896.

Pollard-Durodola Sharolyn et al., (2011) The effects of an intensive shared book-reading intervention for preschool children at risk for vocabulary delay. Except. Children 77 161- 
Scheiner Ester \& Gorsetman Chaya (2009) Do preschool teachers consider inferences for book discussions? Early Child Development and Care 179(5): 595-608.

Scholastic, Y. (2015) Kids and family reading report.

Scholastic, Y. (2016a) Kids and family reading report Australia.

Scholastic, Y. (2016b) Kids and family reading report United Kingdom.

Svensson, Anna- Karin (2009) Reading books in preschool is taken for granted: but is it true?. In Paper presented at the NPFP/NERA conference in Trondheim, March 5-9, 2009.

Thomas Louize, Warren Elizabeth \& deVries, Eva (2011) Play-based learning and intentional teaching in early childhood contexts. Australian Journal of Early Childhood 36(4): 69-75.

Tracey, Diane \& Morrow, Lesley (2017) Lenses on reading: An introduction to theories and models. Guilford Publications.

Wang, Ming- Te \& Holcombe, Rebecca (2010) Adolescents' perceptions of school environment, engagement, and academic achievement in middle school. American educational research journal, 47(3), 633-662.

Worthy, Jo, Chamberlain, Katharine, Peterson, Katie, Sharp, Caron \& Shih, Pei-Yu (2012) The importance of read-aloud and dialogue in an era of narrowed curriculum: An examination of literature discussions in a second-grade classroom. Literacy Research and Instruction, 51(4), 308-322. 